\title{
Hydro-Chemical Analysis of the Ground Water of the Basaltic Catchments: Upper Bhatsai Region, Maharastra
}

\author{
Biswajeet Pradhan* and Saied Pirasteh
}

Institute of Advanced Technologies (ITMA) Spatial \& Numerical Modeling Laboratory University Putra Malaysia, 43400, UPM, Serdang Selangor Darul Ehsan, Malaysia

\begin{abstract}
Water being an excellent solvent tends to dissolve the minerals in the geological system. The chemical nature of the ground water is influenced by several factors such as chemical weathering of the country rocks and interaction with the country rocks. The importance of the hydrochemical analysis underlies the fact that the chemistry of the ground water can directly be rated with the source of water, climate, and geology of the region. In this paper chemical analysis of the ground water has been carried out for upper Bhatsai region in Maharastra. There are eight water quality variables $\left(\mathrm{SO}_{4}{ }^{2-}, \mathrm{Na}^{++}, \mathrm{K}^{+}, \mathrm{Mg}^{2+}, \mathrm{Ca}^{2+}, \mathrm{NO}^{3-}, \mathrm{TH}\right.$, and $\left.\mathrm{pH}\right)$ and the specific Conductance and Total Dissolved Solids were selected for this analysis. In this paper a) The values of water quality parameters were analyzed using statistical methods, b) the existence of trends and the evaluation of the best-fitted models were performed in order to classify the quality of the ground water. The geochemical analysis of the water samples has shown that it is free from certain anomalies and the water is suitable for human and cattle consumption. However, the presence of certain degree of anions indicates that the ground water in the study area is facing stress which could change the quality of the water in the near future.
\end{abstract}

Keywords: Ground water analysis, hydro-chemical, Bhatsai region, India.

\section{INTRODUCTION}

The quality of water resources is a subject of ongoing concern. The assessment of long-term water quality changes is also a challenging problem. During the last decades, water quality of many rivers in India has been done using standard measurements techniques. In the present study, water samples were collected from cased wells during post-monsoon (December) period in order to determine their physical and chemical properties. The location of the samples is given in Fig. (1). Chemical analysis were carried out based on the procedures stipulated by APHA $(1995,1989)$ [1, 2]; and Hem (1959) [3] and the chemical analysis data is given in Table 1. Concentration of total dissolved solids (TDS), total hardness $(\mathrm{TH})$, total carbon oxide $\left(\mathrm{CO}_{2}\right)$ and chloride $\left(\mathrm{Cl}^{-}\right)$ were determined by using the standard methods [4-7].

\section{STUDY AREA}

The study area is situated in upper Bhatsai basin of Maharastra and falling under the latitudes $19^{\circ} 30.9^{\prime}$ and $19^{\circ} 13.18^{\prime}$ and longitudes $73^{\circ} 14.55^{\prime}$ and $73^{\circ} 21.43^{\prime}$, covering an area of approximately $59.5208 \mathrm{~km}^{2}$. The study area falls in the survey of India topological map numbered 47E/7. This is located in the northern part of the Thane district of Maharashtra that includes area around Shahpur and adjacent areas. The location of the study area is shown in Fig. (2) and the location map of the water samples is given in Fig. (1).

\footnotetext{
*Address Correspondence to this author at the Institute of Advanced Technologies (ITMA) Spatial \& Numerical Modeling Laboratory University Putra Malaysia, 43400, UPM, Serdang Selangor Darul Ehsan, Malaysia; Tel: +603-89468466; Fax: +603-86566061;

E-mail: biswajeet24@gmail.com / biswajeet@ lycos.com
}

The study area has a varied morphology. The typical land forms comprises of horizontal basalt, namely the mesas and buttes. Steep scraps are seen in the north-western boundary of the drainage basin (Fig. 3). The topological break in slopes stands as geomorphological evidences as marker for the flow boundaries. In southern part of the study area, there are extensive flatlands, which mark the top of the flow. The valleys are long, deep and straight indicating some structural control.

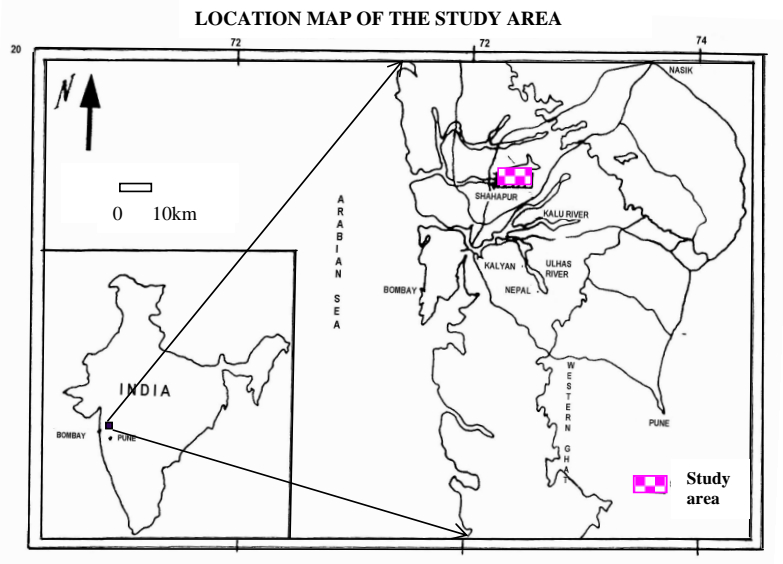

Fig. (1). shows the location map of the study area

The area has a tropical climate receiving rainfall during middle of June to the end of September. The humidity is less compared to the western coast. During the summer time, the temperature goes up to $40^{\circ} \mathrm{C}$. The area is densely vegetated over the scraps and also on the valley side slopes. The culti- 
Table 1. Water Sample Data from Different Location

\begin{tabular}{|c|c|c|c|}
\hline Location & Depth to the Water Table in Meter & Diameter of the Well in Meter & Total Depth of Water in Meter \\
\hline \hline Shahapur & 2.2 & 3.8 & 10.2 \\
\hline Shahapur & 2.75 & 6.8 & 11.7 \\
\hline Shahapur & 2.6 & 3.7 & 12.5 \\
\hline Bendodi & 1.9 & 4.6 & 13 \\
\hline Chimpada & 1.15 & 4.0 & 9 \\
\hline Karade & 1.75 & 3.65 & 12.5 \\
\hline Chandroti & 1.50 & 4.25 & 13 \\
\hline Awale & 1.8 & 3.5 & 10 \\
\hline
\end{tabular}

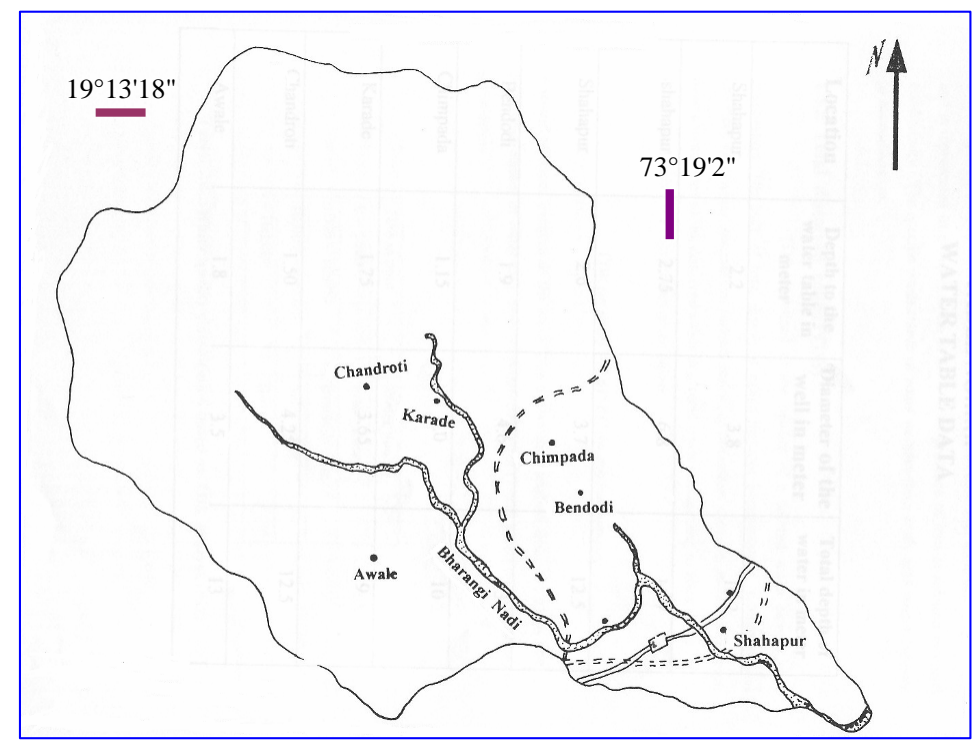

Fig. (2). shows the location map of the collected water sample

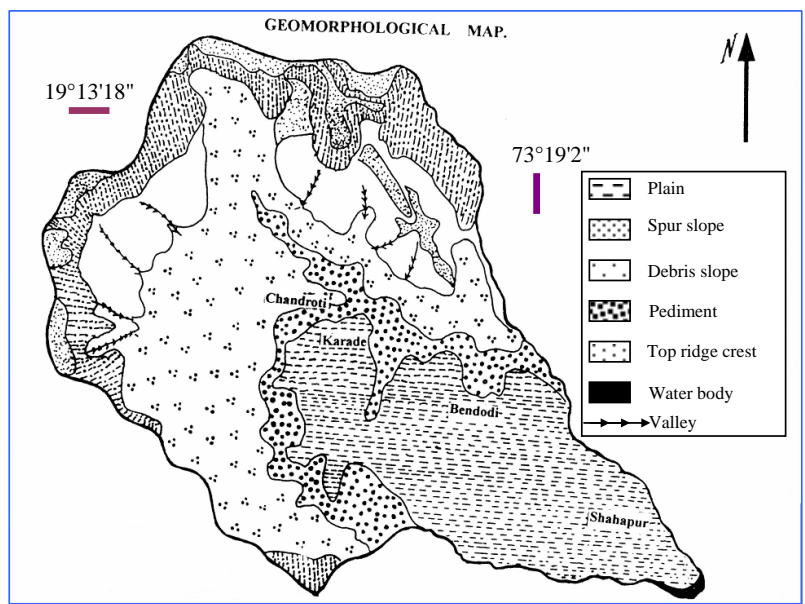

Fig. (3). shows the geomorphological map of the study area

vation is relatively good, limited to the plains and along the fast order stream channels. Soil in the study area is predominantly black cotton soil. The thickness the soil varies from
0.5 meter in the high slope region to about 1.5 meter in the plain lands.

The study area falls within the Deccan Basaltic Province which has an areal extent of over 500, $000 \mathrm{sq}$. km. [8]; covering parts of Maharastra, Karnataka, Andhra Pradesh, Madhya Pradesh and Gujarat and has a maximum thickness of about 2500 meter. Geology of this basaltic country has been extensively studied by Thompson (1836) [9]. Carter (1852) [10] studied the secondary layers which separate the different flows and named them as inter-trappeans. The lithological map of the study area is shown in Fig. (4). A number of fractures zones are traversed through the study area, with each unit showing vertical and horizontal displacements [11]. These fracture systems exhibits a close correspondence with the trends of the dykes cutting across the lava flows.

\section{MATERIALS AND METHODOLOGY}

The physical parameters of the water are colour, odor and turbidity. Colour in ground water may be due to the presence of mineral or organic matter. Turbidity is a measure of suspended materials in water such as clay, silt and microscopic organism. Taste and odor may be derived from bacterial and dissolved gases. Water samples were collected from the 


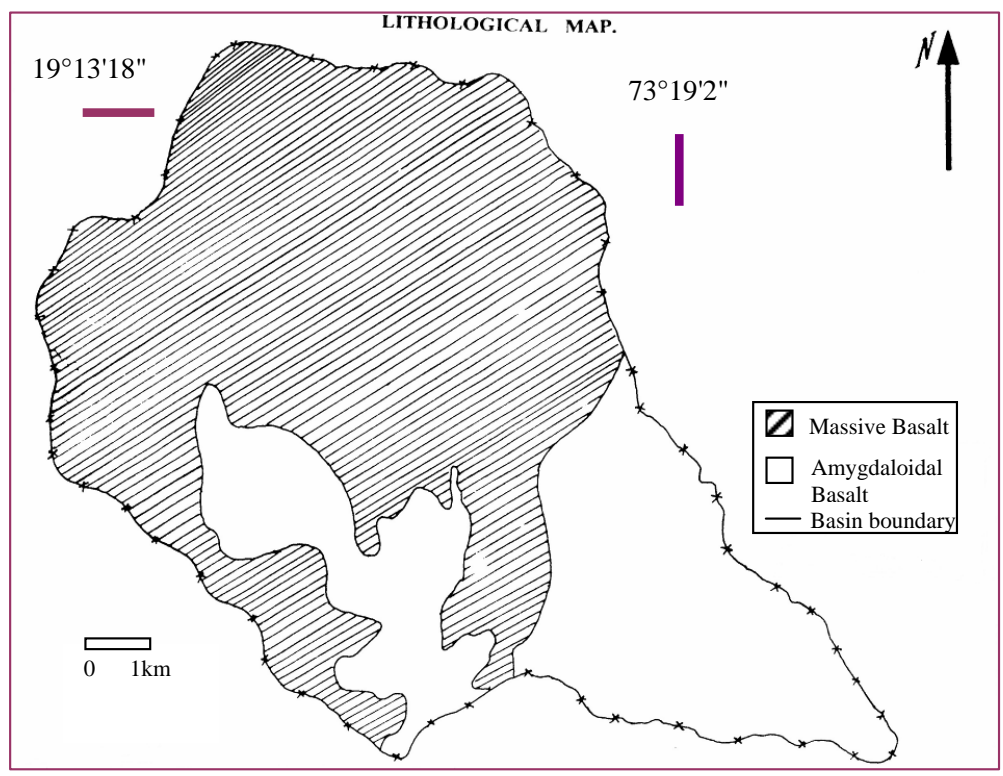

Fig. (4). shows the lithological map of the study area

Table 2. Analytical Data for the Water Samples

\begin{tabular}{|c|c|c|c|c|c|c|c|c|c|c|c|c|c|}
\hline Locality & $\mathbf{p H}$ & $\begin{array}{c}\mathbf{C a}^{++} \\
(\mathbf{e p m})\end{array}$ & $\begin{array}{c}\mathbf{M g}^{++} \\
(\mathbf{e p m})\end{array}$ & $\begin{array}{c}\mathbf{N a}^{+} \\
(\mathbf{e p m})\end{array}$ & $\begin{array}{c}\mathbf{K}^{+} \\
(\mathbf{e p m})\end{array}$ & $\begin{array}{c}\mathbf{H C O}_{3}^{-} \\
+\mathbf{C O}_{3}^{-} \\
(\mathbf{e p m})\end{array}$ & $\begin{array}{c}\mathbf{C l} \\
(\mathbf{e p m})\end{array}$ & $\begin{array}{c}\mathbf{S O}_{4}^{-} \\
(\mathbf{e p m})\end{array}$ & $\mathbf{\%} \mathbf{N a}$ & $\begin{array}{c}\mathbf{T H} \\
(\mathbf{p p m})\end{array}$ & $\begin{array}{c}\mathbf{T D S} \\
(\mathbf{p p m})\end{array}$ & $\begin{array}{c}\mathbf{S A R} \\
(\mathbf{m i c r o} \\
\mathbf{S} / \mathbf{c m})\end{array}$ \\
\hline \hline Shahapur & 6.50 & 5.00 & 6.02 & 1.50 & 1.10 & 6.25 & 7.10 & 0.32 & 19.09 & 551.34 & 690.96 & 0.64 & 1079.62 \\
\hline Shahapur & 7.00 & 3.75 & 2.54 & 1.60 & 0.27 & 5.42 & 2.32 & 0.33 & 22.92 & 250.20 & 399.23 & 0.90 & 623.80 \\
\hline Shahapur & 6.00 & 2.00 & 1.72 & 0.41 & 0.05 & 3.24 & 0.55 & 0.35 & 11.00 & 187.65 & 190.41 & 0.30 & 297.52 \\
\hline Bendodi & 6.75 & 2.16 & 1.41 & 0.51 & 0.04 & 2.97 & 0.46 & 0.57 & 13.35 & 100.08 & 181.55 & 0.38 & 283.67 \\
\hline Chimpada & 7.25 & 2.50 & 2.92 & 0.53 & 0.08 & 4.58 & 1.00 & 0.54 & 10.12 & 108.08 & 275.88 & 0.32 & 431.06 \\
\hline Karada & 6.00 & 3.50 & 3.02 & 0.85 & 0.15 & 5.36 & 1.90 & 0.42 & 13.30 & 125.10 & 361.87 & 0.47 & 565.43 \\
\hline Chandroti & 6.50 & 1.70 & 2.17 & 0.27 & 0.04 & 3.65 & 0.35 & 0.17 & 7.42 & 175.14 & 190.56 & 0.19 & 297.76 \\
\hline Awale & 7.50 & 3.50 & 1.01 & 0.43 & 0.11 & 3.23 & 0.81 & 0.39 & 10.69 & 85.06 & 223.76 & 0.29 & 349.62 \\
\hline
\end{tabular}

study area and in general found to be colourless, odourless and free from turbidity. These water samples were collected from eight different open wells Fig. (4). The detailed chemical analysis data of the collected water samples are given in Table 2.

\subsection{Specific Conductance}

Specific conductance is the conductance of onecentimeter cube of the substances and is represented in micromhos $/ \mathrm{cm}$ at $25^{\circ} \mathrm{c}$. The presence of ions in solution increases conductivity of water. The specific conductance of water samples from the study area varies between 283.67 to 1079.62 micromhos $/ \mathrm{cm}$.

\subsection{Total Dissolved Solids (TDS)}

TDS is defined as the residue of filtered water sample after evaporation. The bulk of total dissolved solids include bicarbonates, sulphates and chloride of calcium, magnesium, sodium, potassium, silica, potassium chloride, nitrate and boron. According to Hem (1959) [3] TDS was calculated using the relationship given below

TDS $($ in ppm $)=0.64 * \mathrm{EC}($ in micromhos $/ \mathrm{cm})$

Analysis of water samples of the study area revealed that the presence of TDS varies between 181.55 to $690.96 \mathrm{ppm}$. Subsequently, four classes of water were proposed based on the procedures adopted from Carroll (1962) [12] and is given in Table 3.

Table 3. Water Quality Classification Based on TDS Content by Carroll (1962)

\begin{tabular}{|c|c|}
\hline TDS in ppm & Water Quality \\
\hline \hline $0-1000$ & Fresh water \\
\hline $1000-10,000$ & Brackish water \\
\hline $10,000-100,000$ & Salty water \\
\hline$>100,000$ & Brine \\
\hline
\end{tabular}




\section{RESULTS AND DISCUSSION}

\subsection{Chemical Constituents}

\subsubsection{Calcium}

Calcium is a major constituent of igneous rocks. The major sources of calcium in ground water around basalts are plagioclase and pyroxene. The range of calcium content in ground water is largely dependent on the solubility of calcium carbonate, sulphide and rarely chloride. The maximum acceptable limit of calcium for domestic use is 75ppm [13]. The calcium content of the water samples were estimated by EDTA titration method. The water samples $\left(500 \mathrm{~cm}^{3}\right)$ were acidified with $10 \mathrm{~cm}^{3}$ of concentrated nitric acid and concentrated to $25 \mathrm{~cm}^{3}$ using evaporation method [14]. After chelation, extraction and subsequent mineralization, calcium ion was determined by atomic adsorption spectrophotometer. The range of calcium varies from 40.08 to $100.20 \mathrm{ppm}$.

\subsubsection{Magnesium}

Magnesium is an important constituent of basalt. It's solubility in water is around five times that of calcium. Calcium and Magnesium together cause the hardness of water. EDTA titration was used to determine the magnesium concentration in the samples. The range of magnesium varies from 12.27 to $73.18 \mathrm{ppm}$.

\subsubsection{Sodium}

Sodium is an important constituent for determining the quality of irrigation water. Sodium bearing minerals like albite and other members of plagioclase feldspars, nephelene and sodalite weather to release the primary soluble sodium products. Most sodium salts are readily soluble in water, but take no active part in chemical reactions. Sodium has wide variations in its concentration in ground water. The sodium content of the samples was determined by a flame photometer. Sodium content in the water samples varies between 6.20 to $34.48 \mathrm{ppm}$.

\subsubsection{Potassium}

Although potassium is nearly as abundant as sodium in igneous rocks, its concentration in ground water is comparatively very less as compared to sodium (nearly one-tenth or one-hundred that of sodium). This is due to the fact that the potassium minerals are resistant to decomposition by weathering. The potassium concentration in the water was determined with the help of Flame photometer. Analysis of water samples in the study area indicates that potassium value varies between 1.57 to $10.97 \mathrm{ppm}$.

\subsubsection{Chloride}

Chloride ion is a predominant natural form of chlorine and is extremely soluble in water. The major sources of chloride in natural water are sedimentary rocks particularly evaporates. Igneous rocks contribute only a fraction of total chloride. Other sources are industrial and domestic wastewater. The limit for domestic purposes is fixed at $250 \mathrm{mg} \mathrm{dm}^{-3}$ [15]. The chloride content in the samples was determined by using $0.1 \mathrm{~N} \mathrm{AgNO}_{3}$ solution. In the present study chloride ion content in all the ground water samples ranged from 12.4 to $251.687 \mathrm{ppm}$.

\subsubsection{Sulphate}

The sulphate content in the atmosphere precipitation is only about $2 \mathrm{ppm}$, but a wide range in sulphate content in ground water is made possible through reduction, precipitation, solution and concentration. The primary mineral sources of sulphate ions include evaporate minerals such as calcium, gypsum and sulphates of magnesium and Sodium. The sulphate concentrations in the water samples were determined by Spectrophotometer. The sulphate content in the samples varies between 8.1 to $26.56 \mathrm{ppm}$.

\subsubsection{Total Hardness TH}

Hardness is often referred to as the soap consuming property of water. Hardness may be divided into two types, carbonate and non-carbonate. Carbonate hardness includes portions of calcium and magnesium, and certain amount of bicarbonates. Total hardness is defined as $\mathrm{TH}=(2.497 \mathrm{Ca}+$ $4.11 \mathrm{Mg}$ ); where $\mathrm{Ca}$ and $\mathrm{Mg}$ are expressed in ppm [16]. Total hardness of the study area varies between 85.06 to 551.34 $\mathrm{ppm}$. Classification of water was done based on hardness given by Sawyer (1960) [17] and is listed in Table 4.

Table 4. Water Classes Based on Hardness by Sawyer (1960)

\begin{tabular}{|c|c|}
\hline Hardness as $\mathrm{CaCO}_{3}$ & Water Class \\
\hline \hline $0-75$ & Soft \\
\hline $75-100$ & Moderately hard \\
\hline $150-3000$ & Hard \\
\hline 3000 & Very hard \\
\hline
\end{tabular}

\subsection{Chemical Parameters}

\subsubsection{Hydrogen Ion Concentration (pH)}

The $\mathrm{pH}$ of a solution is defined as the negative logarithmic of the ion concentration and is normally expressed in moles per liter at a given temperature. $\mathrm{pH}$ of a solution can affect the toxicity of other elements and has very pronounced effect on many chemical reactions which are important to industry, irrigation and domestic water treatment. $\mathrm{pH}$ value falling under 7 indicate the acidic nature of the water. This also accelerates the corrosion rate of metallic substances in water. The $\mathrm{pH}$ value was determined in the field using a $\mathrm{pH}$ paper and the values vary between 7 to 8 .

\subsection{Piper Trilinear Diagram}

In the present study, various cations and anions compositions of many samples were represented by drawing piper trilinear diagram [18]. This diagram permitted the cations and anions compositions of many samples by representing on a single graph in which major groupings or trends in the data can be discerned visually. Because of each analysis is represented by a single point, water with very different total concentrations can have identical representations on this diagram (Fig. 5 and 6). After plotting cations and anions of eight analyzed samples in the piper diagram, it can be observed that the plots mostly fall in Calcium, Magnesium and Carbonate and Bi- Carbonate field. 


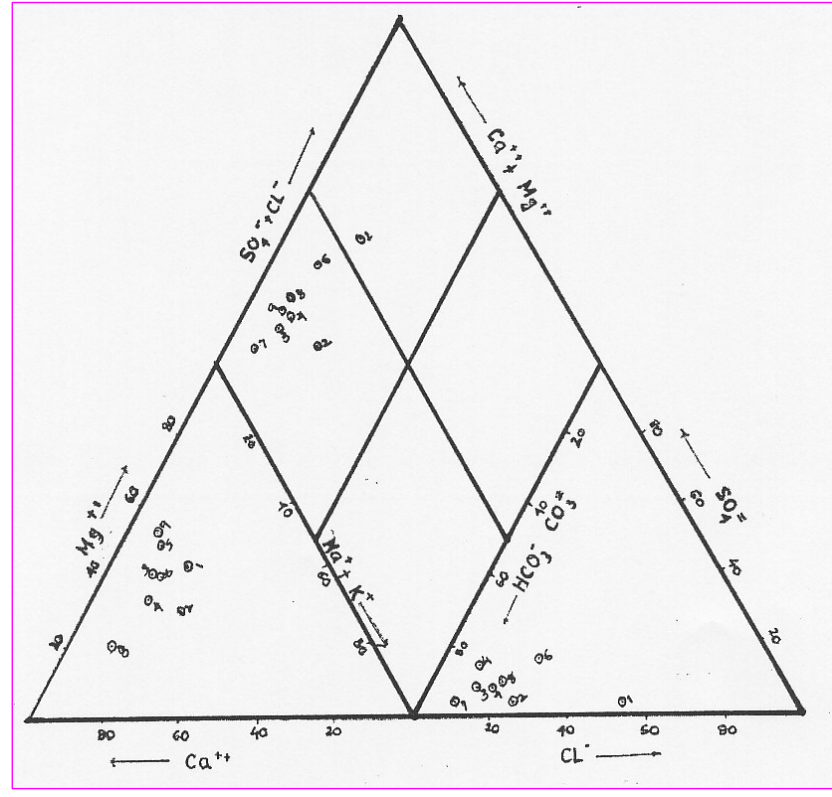

Fig. (5). shows Piper trilinear diagram for the various cations and anions composition of the water samples

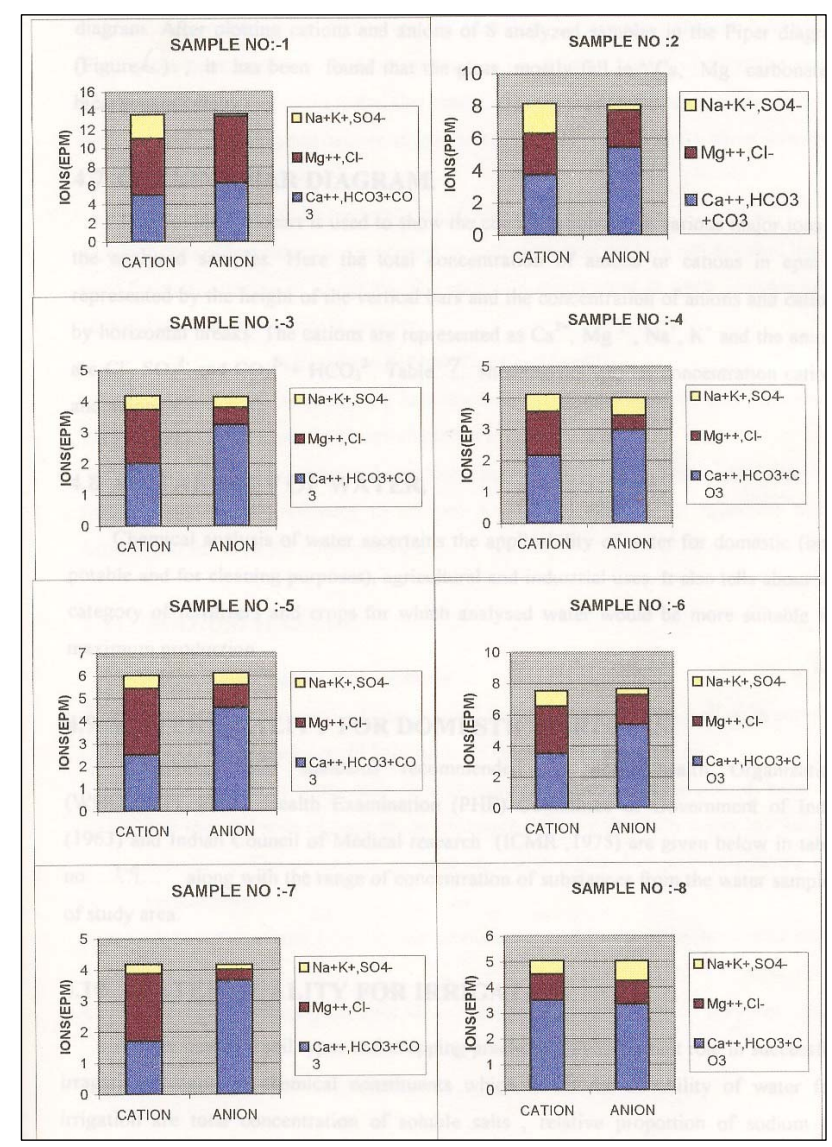

Fig. (6). shows Collins Bar Diagram showing the concentration of various major ions of the analyzed samples

\subsection{Collins Bar Diagram}

The Collin's bar chart was used to show the concentration of various major ions of the analyzed samples [19]. The total concentration of anion or cations in epm is represented by the height to the vertical bars and the concentration of anions and cations by horizontal breaks (Fig. 7). The cations are represented as $\mathrm{Ca}^{2+}, \mathrm{Mg}^{2+}, \mathrm{Na}^{+}, \mathrm{K}^{+}$, and the anions as $\mathrm{Cl}^{-}$, $\mathrm{SO}_{4}{ }^{2-}$ and $\mathrm{CO}_{3}{ }^{2-}+\mathrm{HCO}_{3}{ }^{2-}$.

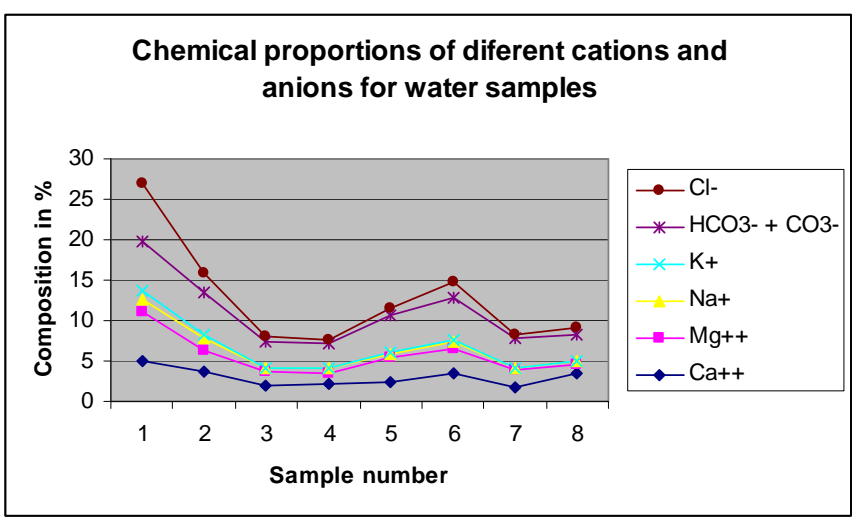

Fig. (7). shows the graph representing the chemical proportions of different cations and anions for water samples

\subsection{Water Quality for Domestic Purposes}

Drinking water standards recommended by world health organization [13], Public Health Examination (PHE) Committee of Govt. of India (1963) and Indian Council of Medical Research (ICMR, 1975) [20-22] are given in Table 5. It also list down the range of concentration of substances in the water samples of studied area. Water quality problems in irrigation include salinity and toxicity. The total dissolved solids content gives the salinity hazard of irrigation water. Presence of excessive sodium content in water makes it unsuitable for irrigation purposes. The sodium hazard in irrigated water is expressed by determining the sodium adsorption ratio (SAR) as stated below

$\mathrm{SAR}=\mathrm{Na} / \mathrm{sqrt}((\mathrm{Ca}+\mathrm{Mg}) / 2)$

In which, the concentrations are expressed in milli equivalents per liter and function 'sqrt' is used for determination of square root. The sodium concentration in water was calculated and is expressed in terms of percentage of sodium and is given by

$\% \mathrm{Na}=((\mathrm{Na}+\mathrm{K}) * 100 /(\mathrm{Na}+\mathrm{Ca}+\mathrm{Mg}+\mathrm{K}))$

Where, all ionic concentrations are expressed in milliequivalents per liter. Increase in percentage of sodium makes water unsuitable for irrigation purposes. The US Ionic Regional Salinity Laboratory has constructed a diagram for classifying irrigation water with reference to Sodium Adsorption ratio as an index for sodium hazards and EC as an index for salinity hazard.

\subsubsection{Sodium Hazard}

According to the US Ionic Regional Salinity Laboratory, alkanity hazard classes are described as follows Table 6 :

1. Low sodium water (s1): It can be used for irrigation purpose for all types of soils with little danger of development of harmful level of exchangeable sodium.

2. Medium sodium water (s2): It represents an appreciable amount of sodium hazards in fine textured soils. These soils constitute higher cations exchange capac- 
Table 5. Drinking Water Standards Recommended by World Health Organization (WHO, 1971), Public Health Examination (PHE) Committee of Govt. of India (1963) and Indian Council of Medical Research (ICMR, 1975) Along with the Range of Concentration of Substances from the Water Samples of Study Area

\begin{tabular}{|c|c|c|c|c|c|c|c|}
\hline \multirow[t]{2}{*}{ Chemical Constituents (ppm) } & \multicolumn{2}{|c|}{ WHO Std. } & \multicolumn{2}{|c|}{ PHE Std. } & \multicolumn{2}{|c|}{ ICMR Std. } & \multirow{2}{*}{$\begin{array}{c}\text { Maximum Concentration in } \\
\text { the Study Area }\end{array}$} \\
\hline & $\mathbf{a}$ & b & $\mathbf{a}^{\prime}$ & $\mathbf{b}^{\prime}$ & $a^{\prime \prime}$ & $b^{\prime \prime}$ & \\
\hline Calcium & 75 & 200 & 75 & 200 & 75 & 200 & 100.20 \\
\hline Magnesium & 30 & 150 & 50 & 150 & 50 & 100 & 73.18 \\
\hline Chloride & 200 & 600 & 250 & 1000 & 200 & 1000 & 251.68 \\
\hline Sulphate & 200 & 400 & 250 & 400 & 200 & 400 & 26.56 \\
\hline $\mathrm{TH}$ & 100 & 500 & 300 & 600 & 300 & 600 & 551.34 \\
\hline TDS & 500 & 1500 & 500 & 1500 & 500 & $* 1500$ & 690.95 \\
\hline
\end{tabular}

$\mathrm{a}=$ maximum acceptable limit $\quad \mathrm{b}=$ maximum allowable limit

$\mathrm{b}^{\prime}=$ Permissible limit $\quad \mathrm{b}^{\prime}=$ excessive limit

$\mathrm{a}^{\prime \prime}=$ Highest desirable limit $\quad \mathrm{b}^{\prime \prime}=$ Maximum permissible level Table

Table 6. Quality of Water Based on SAR by US Ionic Regional Salinity Laboratory

\begin{tabular}{|c|c|c|}
\hline Alkalinity & SAR (meq/l) & Remark on Quality \\
\hline \hline S1 & 10 & Excellent \\
\hline S2 & $10-18$ & Good \\
\hline S3 & $18-26$ & Doubtful \\
\hline S4 & $>26$ & Unsuitable \\
\hline
\end{tabular}

ity especially under low leaching conditions. This water can be used for coarse textures organic soil with good permeability conditions.

3. High sodium water (s3): It may produce harmful levels of exchangeable sodium in most soils.

4. Very high sodium water (s4): it is unsatisfactory for irrigation purposes, except at the salinity level.

\section{CONCLUSION}

Groundwater plays an important role in both private and public water supplies all over the world. Some areas in India have problem of relying on a water-supply system that uses only surface water and water from the well. These areas need an alternative, stable water-acquisition system that can provide high-quality, reliable dirking water. Therefore, this paper presents a statistical approach by using geochemical analysis of the ground water in order to estimate potential quality of the groundwater resources. The water quality data was validated with the existence of trends and the evaluation of the best-fitted models was performed in order to classify the quality of the ground water.

Based on the present study, it can be concluded that for the study area which is covered by basaltic rocks is considered as a hard rock and is generally classified as a poor aquifer. However, since these basaltic rocks areas highly jointed in nature and has suffered a high to moderate degree of weathering, therefore it has converted to a fairly good aquifer. The northern part of the study area is the run off zone.
The drainage area in this region is mature and is saturated with a large amount of infiltration. The geochemical analysis of the water samples revealed that at the present, it is free from anomalies and the water is suitable for human and cattle consumption. This indicates that, the study area is relatively free from the development pressure. However, due to increasing pressure of the population and intensive agricultural activities could lead to the declination of the water quality in the area. The presence of higher amount of certain cations indicates little pollution in the ground water. However, these cations need to monitored over the time in order to keep a sustainable water management in the area. On the other hand, it should not be forgotten that river system plays a major role in assimilation or transporting municipal and industrial wastewater and runoff from agricultural land and mixing with the ground water. Municipal and industrial wastewater discharge in the Bhatsai region constitutes polluting source, whereas surface runoff is a seasonal phenomenon, largely affected by climate within the basin

As a conclusion, in this paper we have documented the fact that the region has high quality drinking water. Rural India is highly dependent on groundwater whereas Indian cities are dependent mostly on surface water. On the other hand, agricultural development and activity are polluting groundwater in many parts of India while rural population growth is rapidly shrinking per capita supply. Therefore, we conclude that the high quality groundwater (that our tests document) in this region should be protected by the responsible agencies for water quality in India by restricting or precluding certain types of activities that have caused serious 
health hazards by contaminating ground water supplies throughout much of rural India.

\section{ACKNOWLEDGMENTS}

Authors would like to thank two anonymous reviewers for their valuable comments which helped us to improve the manuscript. Thanks to the Editorial comments which were very much useful to bring the paper into its current form.

\section{REFERENCES}

[1] APHA. Standard methods for the examination of water and waste water, $19^{\text {th }}$ ed. American Public Health Association 1995

[2] APHA. Standard methods for the examination of water and waste water, $17^{\text {th }}$ Edition; Prepared and published jointly by USA: American Public Health Association 1989.

[3] Hem JD. Study and interpretation of the chemical characteristics of natural water. US Geol Survey Water-Supply Paper 1959; 1473: 261-68.

[4] Trivedi RK, Goyal PK. Chemical and biological methods for water pollution studies. Karad: Environmental Publication 1986.

[5] Suess MJ. Examination of water for Pollution Control UK: Pergamon Press 1982. (Vol. 1, 2).

[6] Jain CK, Bhatia KKS. Physico-chemical analysis of water and waste water. User's manual UM- 26, Roorkee: Nat Inst Hydrol 1987.

[7] Olajire AA, Imeokparia FE. Water quality assessment of Osun River: Studies on inorganic nutrients. Environ Monit Assess 2000; 69:17- 28.

[8] Ravindrakumar. Fundamentals of historical geology and stratigraphy of India. New Delhi: Wiley Eastern Limited 1988.
[9] Thompson RD. Sketch of the Geology of the Bombay islands: Madras. J Lit Sci 1836; 5:159-75.

[10] Carter HJ. Geology of the Island of Bombay. J Bombay Branch R Asiatic Soc 1852; 4: 1-53.

[11] Peshwa VV, Mulay JG, Kale VS. Fractured zones in Deccan traps of western and central India: A study based on remote sensing techniques. J Indian Society Remote Sensing 1987; 15: 9-17.

[12] Carroll D. Rainwater as a chemical agent of geologic processes: a review, USGS Water Supply Paper 1962; 1535p.

[13] WHO (World Health Organisation), International standards for Drinking water, $3^{\text {rd }}$ ed. World Health Organization 1971.

[14] Parker CR. Water Analysis by atomic adsorption spectroscopy, Various Techtoon, Australia: Pty. Lmt 1972.

[15] EPA (United State's Environmental Protection Agency) Is your drinking water safe? Environmental Protection Agency;WH550(570/9) 1989; 89-105.

[16] Todd DK. Groundwater Hydrology. New York: John Wiley \& Sons $1980 ; 535 p$.

[17] Sawyer CH. Chemistry for Sanitary Engineers. New York: McGraw-Hill Book Co., Inc 1960.

[18] Piper AM. A graphic procedure in the geochemical interpretation of water analyses. Trans Amer Geophysics 1944; 25: 914- 23.

[19] Collins WD. Graphic Representations of Water Analysis. Int Eng Chem 1923; 15: 384-94.

[20] ICMR. Manual of standards of quality for drinking water supplies. Indian Council Med Res 1979(44): 21-27.

[21] Bhatia KS, Sharma MK, JAIN CK. Statistical analysis of ground water quality data of Doon Valley, Dehradun. J Appl Hydrol 1999; XII(283): 27-33.

[22] Hem JD. $3^{\text {rd }}$ ed. Study and interpretation of the chemical characteristics of natural water. U.S. Geol. Survey Water-Supply Paper 1989; 2254: 153-263.

(c) Pradhan and Pirasteh; Licensee Bentham Open.

This is an open access article licensed under the terms of the Creative Commons Attribution Non-Commercial License (http://creativecommons.org/licenses/by-nc/3.0/) which permits unrestricted, non-commercial use, distribution and reproduction in any medium, provided the work is properly cited. 